\title{
Assessing Challenges of Inventory Management Pratice (In Case of Dubo Primary Hospital)
}

\author{
Wondmagegn Urgessa Urissa \\ College of Business and Economics, Department of Management Wolaita Sodo University, Ethiopia
}

\begin{abstract}
Inventory is a vital asset, necessary for effective operation of any organization. The key to growing your business is not your strategies, your people or your technology. It is your ability to manage the chain of your vital inputs that you need to create your product and service. The main objective of the study is to find out the challenges of inventory management practice in Dubo primary hospital with respect to their cause and forward possible solutions to mitigate the challenges. Data for the study was collected from different section and department. The major data collection tools were interview and questioner. The finding of this study shows that organization used different items in distinct store method. Even through this method helps to improve management system it highly increase carrying cost of inventories .therefore it is better to the organization if it apply all item at a center store method over all item at distinct store method.
\end{abstract}

Keywords:Inventory management, storage system, replenishment policies

DOI: 10.7176/IEL/9-1-01

\subsection{Introduction}

Material management has gained acceptance in all developing economies. The material department accounts for over $60 \%$ of the cash out flow and $90 \%$ of working capital of the organization. With every five-year plan, the size of the investment has been increasing offering great challenges and opportunities to the material professional (P.Gopalakrishnan, 2011). Management view towards inventory has changed significantly over the past several years previously managers perceived inventory as an asset because it appears as an asset in the firm's financial report (M. Davis, 2013).

Inventories are materials and supplies that a business or institution carries either to provide input for manufacturing and service providing organization. Inventory management is a specialized branch of materials management which supplies for produced and service delivery process. All business organizations require inventories. Inventory management is responsible for planning and controlling inventories from raw materials stage to reach customers (Arnold et.al, 2014)

Generally inventory was the stock of any item resources used in an organization where as inventory management system was the set of policies that monitor and control the level of inventory and determine what levels should be maintained when stock should be replenished and how large order should be. So the basic purpose of maintaining inventory management in manufacturing and stock keeping service was specify when item should be ordered and how long the order should be; that was the reason why the recent trend have modified the simple question of "When and how many" (M. Davis, 2013).

Dubo primary hospital was the public service providing institutions which deliver service for patient. This referral hospital has inventories like drug, ray machine, syringes, microscopes and other medical equipments which are necessary to maintain, facilitate and to improve service delivery process. Even though this organization provide smooth and uninterrupted service to the society, some employers does not give considerable attention for inventory and its importance and they have little awareness and knowledge about the influence that threaten effectiveness of inventory management.

\subsection{Statement of the problem}

In broad terms, customers' service is the ability of company to satisfy the needs of customers. In inventory management, the term was used to describe the availability of items when needed and was a measure of inventory management effectiveness. The customer can be purchaser a distributor, another plant in the organization or the work station where the next operation was to be performed. There are many different ways to measures customers, service each with its strength and weakness but there was no one best measurement. Some measures are percentage of orders shipped on schedule, percentage of line items shipped on schedule and order days out of stock. Inventories help to maximize customer service by protecting against uncertainty. If we could forecast exactly what customers want and when we could plan to meet demand with no uncertainty. However demands and the lead time to get an item are after uncertain, possibly resulting in stock outs and customers dissatisfaction. For these reasons, it may be necessary to carry extra inventory to protect against uncertainty (Arnold, 2014).

Wolcott (2000) explain that inventory management system and inventory control process provide information to efficiently utilize people and equipment, coordinate internal activities communication with 
customers, and David (2015) explains that whether used to provide customers service or to achieve efficiencies the need to carry inventory conflict with the management desire to minimize inventory investment (Samuel, 2014).

Therefore to minimize uncertain and to satisfy customer's satisfaction it was important for employees to have adequate knowledge, awareness and giving adequate attention about organization's inventories. But some employees have little awareness and knowledge about inventory and inventory management its contribution and influencing factor of inventory management. Due to this reason I am initiated to assess the challenges and prospects of inventory management in Dubo primary hospital.

\subsection{Research Questions}

The study would try to answer the following questions.

$>$ What are challenges of inventory management in the organization?

$>$ What type of storage system does the organization use?

$>$ What are the benefits of implementing inventory inspection to the organization?

$>$ What is the inventory management system the organization could use?

$>$ What method does the organization used to dispose expired drugs and other interrupt materials?

\subsubsection{General Objective of the study}

The general objective of the study is assessment of challenges and prospects of inventory management in case of Dubo primary hospital.

\subsubsection{Specific objectives of the study}

- To assess challenges of inventory management in the organization

- To identify types of storage system implemented in Dubo primary hospital.

- To assess the benefits of using effective inventory inspection.

- To assess the activity of inventory management system that the organization can use.

- To Assess disposal method of expired drugs and other interrupt materials.

\section{LITERATURE REVIEW}

Inventory management was specialized branch of material management and plays a great role in integrated approach of material management. It concerned with the physical storage of goods. Inventory management was a technique of utilizing inventory to the maxim tent, so that it generates maximum profit from the last amount of inventory investment without compromising customer satisfaction level. It was keeping the over al cost associated with having inventory as loom as possible without creating problem. It was the process of effectively overseeing the constant in and out flow unit of an existing inventory. It was also seek to control the cost associated with the inventory both from perspective of total value of goods included and tax burden generated by cumulative value of inventory (kale, 2014)

The basic objective of inventory management was to reduce investments on inventory at minimum level, to minimizing carrying cost of inventory and to maximizing profitability. According to Arnold inventory management will have achieving the following objectives: maximizing customer service and Operation efficiency.

According to (Jacobs' 2014) all firms keep supply of inventories for the following reason: To Maintain Independence of Operations, to Meet Variation in Product Demand, to allow flexibility in production scheduling, to provide a safe guarded for variation in a raw material delivery time and to take advantage of economic purchase order sign.

Inventory management system assisted receiving and stores operation by ordering materials in quantities related to standard unit. Load capacity is essential for effective inventory management to reduce investment in inventories and absolute materials. Reducing the damage of material during in house holding will decrease inventory control problems. Reserving personnel can also assist inventory control by promptly rejecting shipment of ordered and unacceptable materials. Effective inventory management system includes the following concerning activities (AK Data. 2013)

An inventory system provides the organizational strokes and the operating policies for maintaining and controlling goods to be stocked. The system is responsible for ordering and receipt of goods: timing the order placement and keeping track of what has been ordered, how much, and from whom. The system also must follow up to answer such question as has the supplier received the order? Has it been shipped? Are the dates correct? Are the procedures established for recording or returning under standadable merchandise? (Silver E. (2011)

According to dabbler and brut planned organized store system is a basic ground to provide consistent service. To do so, dabbler specifies two basic systems that can be used in physically controlling stores system. A single organization often uses both systems at the same time. These combined depends up on the nature of production and the way. In which materials used this system called random access store system. (Dabbler2013).

Items that are in the inventory are not of equal importance in terms of the amount invested, profit potential, 
stock out penalties ....etc. therefore, all items do not deserve the same degree of attention ( J. Elbert 2011).According to Albert some of the popular classification selective control techniques are as follows:- ABC classification, FSN classification and VED classification.

\section{Methodology of the study}

\subsection{Research design}

The research design employed in this study is descriptive and both quantitative and qualitative research approach was used. The rationale behind selection of descriptive design is, it provides an accurate depiction of characteristics of a particular individual, situation, or group. These studies also are a means of discovering new meaning, describing what exists, determining the frequency with which something occurs, and categorizing information. The study involves survey of different document and questionnaire (both close and open ended) and an interview with different employees in the organization.

\subsection{Population and Sampling Technique}

For the purpose of this study, sampling technique used is stratified sampling techniques. Stratified sampling was used to gather data from the employees randomly. It is a probability techniques in which elements in the population has a known and has equal probability of selected in the sample size. The sample size for this study was 80 from the total population of 385 employees.

This sample size was determined based on the following sample determination formula provided by (Kothari, 2004).

- $\mathrm{n}=\mathrm{N} / 1+$ (e) $2=385 / 1+385(0.01) 2=\mathbf{8 0}$

$\mathrm{E}=10 \%=0.01$

$$
\mathrm{N}=385
$$

- $\quad$ Nurses $=92 * 80 / 385=\mathbf{1 9}$

- $\quad$ Midwives $=38 * 80 / 385=\mathbf{8}$

- Laboratory technologies $=20 * 80 / 385=4$

- $\quad$ Surgeon $=1 * 80 / 385=\mathbf{1}$

- $\quad$ Pharmacists $=12 * 80 / 385=\mathbf{2}$

- $\quad$ Anesthetists $=19 * 80 / 385=\mathbf{4}$

- Management $=3 * 80 / 385=1$

- Administrative staff $=200 * 80 / 385=\mathbf{4 1}$

\subsection{Procedures of Data Collection}

Pilot questionnaire was first distributed to around eight employees (one employee from each department). Based on the feedback and the comments, the questionnaire is amended and final questionnaire was developed. The final questionnaire was distributed to around 80 employees to Dubo hospital and 78 of them was filled and returned. Regarding the interview, I have interviewed some people in the organization, as for example supply, logistics manager, inventory manager, and hospital manager. As far as secondary data is concerned, relevant data are collected from the GTP report and literatures, websites (internet) and other available sources.

\subsection{Methods of Data Analysis}

After data collection is completed, data analysis was done in a way that its objectives demand. As much as possible, separate analysis for individual objectives is done. Demographic characteristics are summarized using frequencies and percentages for all variables including: age, sex, work experience, years on the current job/position and educational level. The data gathered through questionnaires were analyzed in quantitative and qualitative data analyses method and presented in the form of charts, diagrams and tables.

\section{Results and Discussions}

This chapter presents the results of the data analysis and discussion of the findings. The first section of this chapter provides the demographic profiles of the respondents and analysis of the different questions in the questionnaire. The second part of this chapter deals with the data gathered from interview with different respondents in different positions. 
4.1 Table 4.1 Background information of respondent.

\begin{tabular}{|c|c|c|c|c|}
\hline Item No & Item & Particulars & No of respondent & Percentage \\
\hline \multirow[t]{2}{*}{1} & Sex & Male & 47 & $60.25 \%$ \\
\hline & & Female & 31 & $39.10 \%$ \\
\hline Total & & & 78 & $100 \%$ \\
\hline \multirow[t]{4}{*}{2} & \multirow[t]{2}{*}{ Age } & $20-35$ & 57 & $73.07 \%$ \\
\hline & & $36-45$ & 9 & $11.53 \%$ \\
\hline & & $46-60$ & 12 & $15.38 \%$ \\
\hline & & Above & - & - \\
\hline Total & & & 78 & $100 \%$ \\
\hline \multirow[t]{5}{*}{3} & Education Level & $12^{\text {th }}$ completed & - & - \\
\hline & & Diploma & 35 & $44.87 \%$ \\
\hline & & Degree & 26 & $33.33 \%$ \\
\hline & & Masters & 11 & $14.10 \%$ \\
\hline & & Doctors & 6 & $7.69 \%$ \\
\hline Total & & & 78 & $100 \%$ \\
\hline
\end{tabular}

Source; own survey, 2018

According to the above table 4.1 out of 78 respondent $47(60.25 \%)$ of respondent were male, $31(39.10 \%)$ were female. Regarding age of the respondent 57(73.07\%) were between age 20-35, 9(11.53\%) were between age 36-45 and $12(15.38 \%)$ were between age 46-60. Regarding educational level 35(44.87\%) were diploma, $26(33.33 \%)$ were degree, 11(14.10\%) were master's and 6(7.69\%) were doctor's. regarding work experiences 20 (25.64\%) have than year work experience and $21(26.92 \%)$ have 6-10 year work experience. Depending on respondent's reaction, one can conclude most employees of the organization are qualified in diploma level followed by degree holders and the experience they had on the organization as well as the their current job is very good. This enables them to point out the emerging inventory challenges and activities.

Table 4.2 Employees' knowledge on contribution of inventory for organization and availability of enough ware houses.

\begin{tabular}{|l|l|l|l|}
\hline Questions Asked & Particulars & $\begin{array}{l}\text { Number of } \\
\text { Respondents }\end{array}$ & $\begin{array}{l}\text { Percentage } \\
(\%)\end{array}$ \\
\hline $\begin{array}{l}\text { Do you think inventory have a sustainable contribution for the } \\
\text { organization }\end{array}$ & Yes & 78 & $100 \%$ \\
\hline Total & No & - & -- \\
\hline & & $\mathbf{7 8}$ & $\mathbf{1 0 0 \%}$ \\
\hline Does the organization have enough ware house for inventories & Yes & 48 & $61.53 \%$ \\
\cline { 2 - 4 } & No & 30 & $38.46 \%$ \\
\hline Total & & $\mathbf{7 8}$ & $\mathbf{1 0 0 \%}$ \\
\hline
\end{tabular}

Source: own survey, 2018

As shown in the above table 4.2 all of 78 respondent or $78(100 \%)$ of respondent response that inventory have a sustainable contribution for the organization. this indicates that all respondent have knowledge about the contribution of inventory for the organization. Regarding enough warehouse 48(61.53\%) of respondent said that the organization have enough ware house for inventories and $30(38.46 \%)$ of respondent said that the organization have no enough ware house for inventories. This indicates that the organization have minimum shortage of ware house for inventories.

Table 4.3 Inventories storage method and storage system

\begin{tabular}{|l|l|l|l|}
\hline Questions Asked & Particulars & $\begin{array}{l}\text { Number } \begin{array}{c}\text { of } \\
\text { Respondents }\end{array} \\
\text { Percentage } \\
(\%)\end{array}$ \\
\hline \multirow{2}{*}{$\begin{array}{l}\text { How inventories are stored with in ware } \\
\text { house }\end{array}$} & $\begin{array}{l}\text { All items are stored with in ware } \\
\text { house }\end{array}$ & 24 & $30.76 \%$ \\
\cline { 2 - 4 } & $\begin{array}{l}\text { Different items are stored at different } \\
\text { area of store }\end{array}$ & 54 & $69.23 \%$ \\
\hline Total & & $\mathbf{7 8}$ & $\mathbf{1 0 0 \%}$ \\
\hline \multirow{2}{*}{$\begin{array}{l}\text { What type of storage system does your } \\
\text { organization uses }\end{array}$} & Open store & 30 & $38.46 \%$ \\
\cline { 2 - 4 } & Closed store & 48 & $61.15 \%$ \\
\cline { 2 - 4 } & Random access store & - & - \\
\hline Total & & $\mathbf{7 8}$ & $\mathbf{1 0 0 \%}$ \\
\hline
\end{tabular}

Source, Own survey 2018 
As indicate in the above table 4.4. 24(30.76\%) of respondent said that stored within warehouse and $54(69.23 \%)$ of them ware said that different items are stored at different areas of store. This indicates that organization is mostly use different items at distinct store method. So the organization keeps drugs of medical equipments in independent, separable and distinct storage areas. Concerning storage system 30 (38.46\%) of respondents said that the organization was used open store and $48(61.15 \%)$ of respondents said that the origination was used closed store this indicates that most of time inventories are in and out flow through the permission of inventory manager, but sometimes according to the nature of inventories the organization was control in and out flow inventories through the open store system.

Table 4.4 implementing rule procedures of inventory management

\begin{tabular}{|l|l|l|l|}
\hline Questions Asked & Particulars & $\begin{array}{l}\text { Number } \\
\text { Respondents }\end{array}$ & $\begin{array}{l}\text { Percentage } \\
(\mathbf{\%})\end{array}$ \\
\hline \multirow{2}{*}{$\begin{array}{l}\text { How do you see your organization } \\
\text { on applying rules and procedures } \\
\text { of inventory management }\end{array}$} & Very high & - & - \\
\cline { 2 - 4 } & High & 34 & $43.58 \%$ \\
\cline { 2 - 4 } & Neutral & 10 & $12.28 \%$ \\
\cline { 2 - 4 } & Low & 34 & $43.58 \%$ \\
\cline { 2 - 4 } & Very & - & - \\
\hline Total & & $\mathbf{7 8}$ & $\mathbf{1 0 0 \%}$ \\
\hline
\end{tabular}

Source: own survey 2018

According to the above table 4.5 out of 78 respondent $34(43.58 \%)$ of them said that the organization is applying rules and procedures of inventory management, $10(12.28 \%)$ of them respondent that the organization being a neutral to apply rules and procedures of inventory management and 34(43.58\%) of respondent said that the organization was mostly not used rule and procedures of inventory management

Table 4.5 counting and inspection of inventories

\begin{tabular}{|c|c|c|c|}
\hline Questions Asked & Particulars & $\begin{array}{l}\text { Number } \\
\text { Respondents }\end{array}$ & $\begin{array}{l}\text { Percentage } \\
(\%)\end{array}$ \\
\hline \multirow{2}{*}{$\begin{array}{l}\text { Does the organization have implementing } \\
\text { counting and inspection of drugs and } \\
\text { medical equipments }\end{array}$} & Yes & 78 & $100 \%$ \\
\hline & No & - & - \\
\hline Total & & 78 & $100 \%$ \\
\hline \multirow[t]{4}{*}{ How often inspection were take place } & Weekly & - & - \\
\hline & Monthly & 16 & $20.51 \%$ \\
\hline & Semi-annual & 42 & $53.84 \%$ \\
\hline & Annually & 20 & $25.64 \%$ \\
\hline Total & & 78 & $100 \%$ \\
\hline
\end{tabular}

Source, Own survey 2018

According to the above table $4.5,78(100 \%)$ of respondent responded that the organization implementing counting and inspection of drugs and medical equipments. This indicates that the organization was applied a regular counting and inspection of inventories therefore the organization could clearly decide about when and how much order will required in the future. Regarding the time inspection were taken out of 78 respondent $16(20.51 \%)$ responded that the organization was taken monthly inspection of inventory, $42(53.84 \% 0$ of respondent said that the organization was taken semi- annually inspection of inventories and $20(25.64 \%)$ of respondent said that the organization was taken annually inspection of inventories. This indicates that most of time of organization was taken semi- annually inspection of inventory, but according to the nature of inventory, sometimes inspections were taken place in each monthly and annually. 
Table 4.6 challenges and practice of inventories management

\begin{tabular}{|c|c|c|c|}
\hline Questions Asked & Particulars & $\begin{array}{l}\text { Number of } \\
\text { Respondents }\end{array}$ & $\begin{array}{l}\text { Percentage } \\
(\%)\end{array}$ \\
\hline \multirow[t]{4}{*}{$\begin{array}{l}\text { What challenges of inventory management } \\
\text { does the organization faces }\end{array}$} & $\begin{array}{l}\text { Complexity of ordering ad } \\
\text { stocking of an items }\end{array}$ & 11 & $14.10 \%$ \\
\hline & Difficulty of supplies performance & 25 & $32.05 \%$ \\
\hline & Scarcity of materials & 34 & $43.58 \%$ \\
\hline & Damage of product( of an items & 8 & $10.25 \%$ \\
\hline Total & & 78 & $100 \%$ \\
\hline \multirow{2}{*}{$\begin{array}{l}\text { What inventories management system does } \\
\text { the organization }\end{array}$} & Item inventories management & 40 & $51.28 \%$ \\
\hline & $\begin{array}{l}\text { Aggregate inventories } \\
\text { management }\end{array}$ & 38 & $48.71 \%$ \\
\hline Total & & 78 & $100 \%$ \\
\hline
\end{tabular}

Source: own survey, 2018

As indicate in the above table 4.6 out of 78 respondent $11(14.10 \%)$ said that the organization was challenging complexity of ordering and stocking of an items, $25(32.05 \%)$ respond that the organization was faced difficulty of supplier performance, $34(43.58 \%)$ said that the organization was faced scarcity of materials and difficulty of supplier performance, but sometimes it also face the problem of complexity of ordering, stocking and damage of product. Concerning inventory management system out of 78 respondents 40 (51.28\%) respond that the organization was used item inventory management while $38(48.71 \%)$ of them said that the organization would be use an aggregate inventory management. This indicates that the organization would be uses both item and aggregate inventory management, but it favors item inventory management than aggregate inventory management.

Table 4.7 inventory management and performance of the organization

\begin{tabular}{|l|l|l|l|}
\hline Questions Asked & Particulars & $\begin{array}{l}\text { Number of } \\
\text { Respondents }\end{array}$ & $\begin{array}{l}\text { Percentage } \\
(\mathbf{\%})\end{array}$ \\
\hline How do view the performance of your organization on drug and $\begin{array}{lll}\text { medical equipments } \\
\text { mery }\end{array}$ & Very high & 22 & $28.20 \%$ \\
\cline { 2 - 4 } & High & 22 & $28.20 \%$ \\
\cline { 2 - 4 } & Neutral & 17 & $21.79 \%$ \\
\cline { 2 - 4 } & Low & 17 & $21.79 \%$ \\
\cline { 2 - 4 } & Very & - & $\mathbf{1 0 0 \%}$ \\
\hline Total & & $\mathbf{7 8}$ & $\mathbf{1 0 0 \%}$ \\
\hline
\end{tabular}

Source: own survey, 2018

According to the above table $4.13,22(28.20 \%), 22(28.20 \%), 17(21.79 \%)$ and $17(21.79 \%)$ of respondents respond very high neutral and low respectively . these indicates that the organization is performing well in drug and medical equipment but sometimes low performance of the organization was seen on drug and medical equipments.

Tables 4.8 disposal and disposal method of expired and scrap material.

\begin{tabular}{|l|l|l|l|}
\hline Questions Asked & Particulars & $\begin{array}{l}\text { Number } \\
\text { Respondents }\end{array}$ & \multicolumn{1}{c|}{$\begin{array}{l}\text { Percentage } \\
(\%)\end{array}$} \\
\hline $\begin{array}{l}\text { Does the organization dispose an expired } \\
\text { drugs and scrape material timely }\end{array}$ & Yes & 60 & $76.92 \%$ \\
\cline { 2 - 4 } Total & No & 18 & $23.07 \%$ \\
\hline & & $\mathbf{7 8}$ & $\mathbf{1 0 0 \%}$ \\
\hline $\begin{array}{l}\text { By what method capered scrap material } \\
\text { disposed }\end{array}$ & By classification & 39 & $50 \%$ \\
\cline { 2 - 4 } & By codification & 39 & $50 \%$ \\
\hline Total & & $\mathbf{7 8}$ & $\mathbf{1 0 0 \%}$ \\
\hline
\end{tabular}

Source: own survey, 2018

As above table 4.8 shows out of 78 respondents $60(76.92 \%)$ of respondents said that the organization was dispose an expired drugs and scrap materials timely and 18(23.07\%) of them said that the organization was not dispose an expired scrap materials timely. this indicates that most of the time the organization was disposed expired scrap material timely, but sometimes if faces a problem to dispose them. Regarding disposal method $39(50 \%)$ of respondents said that the organization was use classification and also $39(50 \%)$ of them said that the organization is used codification. this shows that the organization is use both codification and Classification system equally to dispose unwanted items. 
Table 4.9 the availability of computerized inventory recording system

\begin{tabular}{|l|l|l|l|}
\hline Questions Asked & Particulars & $\begin{array}{l}\text { Number } \\
\text { Respondents }\end{array}$ & \multicolumn{1}{|l|}{$\begin{array}{l}\text { Percentage } \\
(\%)\end{array}$} \\
\hline $\begin{array}{l}\text { Does the organization inventory } \\
\text { management system was assigned by the } \\
\text { computer }\end{array}$ & Yes & 58 & $74.35 \%$ \\
\hline Total & & 20 & $25.64 \%$ \\
\hline
\end{tabular}

Source: own survey, 2018

From the above table 4.16, we understand that, out of 78 respondents $40(74.35 \%)$ said that the organization inventory management system was assigned by computer and 20(25.64\%) of respondents said that it was not assigned by computer. this indicates that the organization has a computerized inventory recording system as many respondents respond, but, there may be a problem of inventory recordings through computer.

\subsection{Conclusions}

Inventory management is one of the crucial element that enable organization to provide smooth and un interrupted service for the society the study has been concluded the research major findings as follow.

$>$ Regarding to respondent background information most of employees are young and found in productive age most of them are diploma holder and degree holder and have 1-5 years work experience

$>$ This implies that most of employees could easily understand questionnaires and also they have at least one year work experience, so they are familiar with inventory management practice.

$>$ Based on the major findings mostly inventories were stored in separate distinct house. This helps to clear counting and inspection of material seen through most of the time inventories are stored in distinct area sometimes the organization stores all items at a center store method. At this in order to easily count and identification each type of inventories from a center store the organization on forced to use both codification and classification system.

$>$ According to major findings inventories inspection were taken place in semi-annual interval. This implies that by considering the effect of deterioration and expired drugs has on the health of society ,organization strictly control in and out going of drugs medical equipments through via implementation of closed store sea stem.

$>$ Based on the major findings the organization insures on time implementation of drugs and medical equipments. Through on time replacement of drug and medical equipments the organization enables to offer consistent health care service to the society. On time counting replacement of inventories help to overcome sock out problem, which arise due to shortage of required inventories. From this

$>$ This implies that by considering the effect of deterioration and expired drugs has on the health of society, organization strictly control in and out going of drugs medical equipments through via implementation of closed store sea stem.

$>$ Based on the major findings the organization insures on time implementation of drugs and medical equipments. Through on time replacement of drug and medical equipments the organization enables to offer consistent health care service to the society. On time counting replacement of inventories help to overcome sock out problem, which arise due to shortage of required inventories. From this

\section{Recommendation}

$>$ After the above observation the following idea could be provided as recommendation for effective inventory management to be implemented in Dubo primary hospital.

$>$ Warehouse is the great aspect of inventory management that the manager of inventories should have give advice for employees to give considerable attention to store inventories. Appropriate store management play a vital role to the performance of business operation.

$>$ More over to improve inventory management performance and to reduce cost associated with inventories it is advisable to hiring qualified personnel in the arias of inventory management.

> Classification of inventory was important to eliminate duplication of items in warehouse and to achieve a physical control of inventories. The codification and classification of are advisable to account the functions and technical nature of materials. The organization used deferent it elms at the distinct store method. Due the separate layout materials these storing methods help the organization to easily count, check and identify individual items. These methods enable organization to perform effective inventory inspection. Even though this enable to perform effective counting, identification and inspection of materials it needs many warehouse for each unique group of inventories which require high amount of capital. On the contrary, if the organization applies all items at a center store method it enables the organization to reduce inventory cost. But it difficult easily counts, check and identifies the required items from collectively stored over all inventories. However this problem is solved by classification $\mathrm{n}$, identification and by frequent regular 
inspection. So it is better to the organization if it apply all items at a center store method.

$>$ The availability of adequate inventory enables organization to deliver uninterrupted service to the society. Providing effective service requires the availability of excess amount of inventories. As result some inventories would be deteriorate, obsolete and expired. In order to remove these unwanted inventories, the organizations sometimes use fire and burn them. Drugs by its nature composed from so many chemicals, so burning drugs causes' air pollution. These directly affect health and safety of the society and environment. Therefore it was better to the organization to find other less risky disposal method such as putting under the ground.

\section{References}

- A grawa (2014), production and operation management $5^{\text {th }}$, Dilshad garden, New Delhi

- $\quad$ Ahuja, R. (2015) principle of material management $3^{\text {rd }}$ New Delhi

- $\quad$ AkDatta, (2014), material management $2^{\text {nd }}$ New Delhi

- Dobler M and Burt ( 2013) introduction to material management, $4^{\text {th }}$ New Delhi

- Jacobos F.R (2O11), manufacturing, planning and control for supply chain management $4^{\text {th }}$ Newwork mc Graw hill.

- J.Elbert(2010), production and operation management, $5^{\text {th }}$ ed New delhi

- J.R Tony Arnold, Stephen N and Chapman (2014) introduction to material management $5^{\text {th }}$ New Delhi Kitheka Samson Samuel (2014) international journal of research in management and business studies ( ISMBS), university of Nairobi

- Mark m. daviis, microholas j aquiline and rechard b chase (2013) fundamental of operation management $4^{\text {th }}$ ed me graw hill.

- $\quad$ N.Chapman and m.clive (2015) MATERIAL MANAGEMENT $6^{\mathrm{TH}}$, KINDERSLY INDIA

- P. Gopalakrishan ( 2011), handbook of material management, EEE, ( EASTYERN ECONMY EDITION)

- $\quad$ R- Peterson ( 2012) decision system for inventory and material $4^{\text {th }}$ New York

- $\quad$ Shailendra kale (2013), production and operation management, $6^{\text {th }}$, Green park extension, New Delhi.

- $\quad$ Silver e ( 2011), decision system for inventory management and production planning and control, $3^{\text {rd }}$, New York Wiley

- $\quad$ Tersine R.J (2012) principle of inventory and materials management, 4th New York, North Holland.

- Wild T. (2010), best practices ininventory management $5^{\text {th }}$, New York

- $\quad$ Zip kin P.H ( 2000) foundation of inventory management, $6^{\text {th }}$, New York ( Irwin), McGraw Hall 